\title{
The Hox-1.3 homeo box protein is a sequence-specific DNA-binding phosphoprotein
}

\author{
Ward F. Odenwald, ${ }^{1}$ James Garbern, ${ }^{1}$ Heinz Arnheiter, ${ }^{1}$ Elizabeth Tournier-Lasserve, ${ }^{1}$ and Robert A. \\ Lazzarini $^{2}$
}

\begin{abstract}
${ }^{1}$ Laboratory of Viral and Molecular Pathogenesis, National Institute of Neurological Diseases and Stroke, National Institutes of Health, Bethesda, Maryland 20892 USA; ${ }^{2}$ Brookdale Center for Molecular Biology, Mount Sinai School of Medicine, New York, New York 10029 USA
\end{abstract}

\begin{abstract}
We report that the murine Hox-1.3 homeo domain protein is a nuclear phosphoprotein capable of binding to specific DNA sequences. DNase I protection of the Hox-1.3 gene promoter region with the Hox-1.3 protein identifies a binding site 144 bp upstream from the start of transcription. Both phosphorylated and nonphosphorylated forms bind DNA directly in a sequence-specific manner. Electrophoretic mobility shift assays were performed with a set of synthetic oligonucleotides representing either the DNase I-protected region of the Hox-1.3 gene or partially homologous sequences present in promoter regions of other characterized viral, yeast, and mammalian genes. From the results, we deduce a consensus binding motif of CPyPyNATTAT/GPy. Base substitutions in the core ATTA sequence severely reduce or abolish binding. In the SV40 enhancer, the Hox-1.3 binding motif overlaps both the octamer (Octa2) and the transactivator protein-1 (AP-1) binding sites. The Hox-1.3 binding motif also overlaps the nuclear factor III (NF-III) octamer motif in the adenovirus-2 origin of DNA replication. Overlap among DNA-binding sites suggests that regulation imparted by certain ciselements may be integrated by these different factors.
\end{abstract}

[Key Words: Hox-1.3; homeo domain-DNA binding; phosphoprotein]

Received September 16, 1988; revised version accepted December 12, 1988.

The molecular mechanisms that govern both DNA replication and gene expression are the instruments affecting developmental processes. Interactions between regulatory factors, their DNA-binding sites, and other components of the molecular machinery play fundamental roles in the realization of the developmental programs. Genetic analysis of these processes in the fruit fly Drosophila melanogaster has identified a number of genes whose correct function is required for both the elaboration and identity of its body parts (Ouweneel 1976; Nüsslein-Volhard and Wieschaus 1980). Many of these genes contain a homeo box sequence and encode homeo domain containing nuclear proteins (McGinnis et al. 1984; Scott and Weiner 1984; for review, see Gehring 1987). The presence of multiple copies of the homeo box sequence in the genomes of eukaryotes indicates that the encoded proteins represent a conserved family of related proteins with shared characteristics (McGinnis et al. 1985; Holland and Hogan 1986).

The most conserved region of the homeo domain shares amino acid sequence and structural similarities with DNA-binding, regulatory proteins known to con- trol cell fate, such as the yeast mating-type $M A T \mathbf{a} 1$ and MAT 2 proteins (Laughon and Scott 1984; Shepherd et al. 1984). These observations have led to the proposal that homeo domain proteins function by binding to cisacting regulatory elements and modulating the transcriptional activity of specific genes. In support of this hypothesis, DNA-binding studies employing either homeo domain fusion proteins or full-length homeo domain proteins synthesized in Escherichia coli have demonstrated that a structural element resides within the homeo domain, which binds DNA in a sequence-specific manner (Desplan et al. 1985; Fainsod et al. 1986; Cho et al. 1988; Hoey and Levine 1988). Additionally, Hiromi and Gehring (1987) have provided functional evidence that the Drosophila homeo box gene, fushi tarazu (ftz), is autoregulated; although direct DNA-binding studies have not yet been published, the presence of the ftz protein is required for the proper functioning of its own transcriptional enhancer.

The observation that divergent Drosophila homeo domain proteins recognize similar DNA sequences (Hoey and Levine 1988) suggests that these proteins represent a 
family of regulatory factors that compete for similar DNA-binding sites and, once bound, perform unique or similar functions (Desplan et al. 1985; Harding et al. 1985). Sequence homology between the DNA targets of different binding proteins has been observed with nonhomeo-domain proteins, as well. In yeast, both the AP-1 and GCN-4 transcription factors bind to similar DNA sites, but, nonetheless, affect expression of relevant genes differently (Harshman et al. 1988). The tissue specific and ubiquitous proteins that bind the octamer (Rosales et al. 1987) or CCAAT box (Dorn et al. 1987; Santoro et al. 1988) sequences represent other families of regulators that share DNA target sites.

Here, we report that the murine Hox-1.3 protein (Odenwald et al. 1987; Fibi et al. 1988), prepared with the aid of a eukaryotic expression system, is a nuclear protein that undergoes multiple phosphorylation events. Multiple endogenous Hox-1.3 forms are also present in the nuclei of cultured fibroblasts, and their differential salt elution from nuclei suggests that phosphorylated forms bind more avidly to nuclear sites. Both phosphorylated and unphosphorylated forms are sequence-specific DNA-binding proteins. The DNA target sequence of the Hox-1.3 homeo domain protein (CPyPyNATTAT/ $\mathrm{GPy} /$ is present, both in origins of DNA replication and in cis-regulatory elements that control cellular and viral gene expression. Many of these cis-regulatory elements contain Hox-1.3 DNA-binding sites that either lie within, overlap with, or are adjacent to other sequence motifs recognized by non-homeo-domain transcription and/or DNA replication factors. These observations suggest that in addition to intrafamily competition, homeo domain proteins may also compete with other families of regulatory proteins for DNA-binding sites.

\section{Results}

Multiple forms of recombinant Hox-1.3 protein accumulate in the nuclei of spodoptera frugiperda cells

Previously, we reported several characteristics of the Hox-1.3 homeo domain protein extracted from cultured fibroblasts or the central nervous system (CNS) of midgestation mouse embryos that suggested the protein was post-translationally modified. The proteins migrated aberrantly in SDS-polyacrylamide gels and could be resolved as several immunoreactive bands with apparent molecular weights that were larger than those predicted from the DNA sequence (Odenwald et al. 1987; M. Tani et al., unpubl.). These observations guided us in the selection of a recombinant DNA expression system for the generation of substrate amounts of the Hox-1.3 protein. The baculovirus expression system was chosen because of its demonstrated high yield of recombinant protein and the ability of the eukaryotic host cells (Spodoptera frugiperda) to post-translationally modify recombinant nuclear proteins, such as c-myc (Miyamoto et al. 1985), in a correct manner.

Double homologous recombination between the wildtype baculovirus genome and the shuttle vector pAC YM-1-Hox-1.3 (see Methods) yielded a polyhedrin-nega- tive recombinant virus containing a single copy of a polyhedrin-Hox-1.3 gene. Controlled by the polyhedrin promoter, the hybrid gene encodes an RNA that contains (in $5^{\prime} \rightarrow 3^{\prime}$ order) all of the polyhedrin $5^{\prime}$-untranslated leader, a 14-base synthetic linker, 833 bases of Hox-1.3 cDNA sequence, starting at the presumed initiation codon and ending 18 bases $3^{\prime}$ of the termination codon (Odenwald et al. 1987), fused to the polyhedrin 3 '-untranslated trailer. The 5 '- and $3^{\prime}$-untranslated portions of the endogenous Hox-1.3 cDNA contain sequences which may either reduce the translation efficiency (Bürglin et al. 1987) or message stability (Shaw and Kamen 1986), and the deletion of these sequences from the recombinant DNA construction should be noted.

Twenty hours postinfection with the plaque-purified recombinant virus, phase-dense intranuclear masses appeared in the $S$. frugiperda cells. By $40 \mathrm{hr}$, these masses occupied $>50 \%$ of the nuclear volume. Immunofluorescent studies with either Hox-1.3 peptide-specific, rabbit polyclonal, or mouse monoclonal antibodies (see Methods) identified the structures as Hox-1.3 accumulations (Fig. 1).

The nuclear proteins extracted from $S$. frugiperda cells $36 \mathrm{hr}$ post infection were separated by SDS-polyacrylamide gel electrophoresis, transferred to nitrocellulose, and probed with monoclonal or polyclonal antibodies directed against the Hox-1.3 protein. Multiple, distinct forms of the Hox-1.3 immunoreactive proteins were identified with apparent molecular weights of 35-43 $\mathrm{kD}$. No cross-reacting proteins were detected in extracts obtained from uninfected cells or cells infected with wild-type virus or unrelated recombinant virus (Fig. 2). In our previous report, we had estimated the apparent molecular weights of fibroblast Hox-1.3 forms to be $\sim 32-35 \mathrm{kD}$. Longer electrophoresis times and comigration of recombinant and fibroblast Hox-1.3 proteins (Fig. 4 ) indicate that $\sim 35-43 \mathrm{kD}$ is a closer approximation of the apparent molecular weights.

\section{Hox-1.3 is a nuclear phosphoprotein}

We performed a series of experiments designed to determine whether the multiple forms of Hox-1.3 were the result of post-translational modifications and what the nature of those modifications might be. Pulse-chase experiments, followed by immunoprecipitation of the labeled protein, revealed that $\left.{ }^{35} \mathrm{~S}\right]$ methionine first appeared in the fastest migrating form and only later in the slower migrating forms. The labeling of the slower migrating forms took place during the cold methionine chase, indicating that they were not directly labeled with free $\left.{ }^{35} S\right]$ methionine but were likely derived from the first labeled material. The appearance of multiple forms also suggested that Hox-1.3 protein was undergoing multiple modifications. Additionally, the comparison of the ${ }^{35} \mathrm{~S}$-labeled immunoprecipitates with those obtained from cells incubated with [ $\left.{ }^{32} \mathrm{P}\right]$ orthophosphate demonstrated that the slower migrating forms are phosphorylated, whereas no phosphate was detected in the 

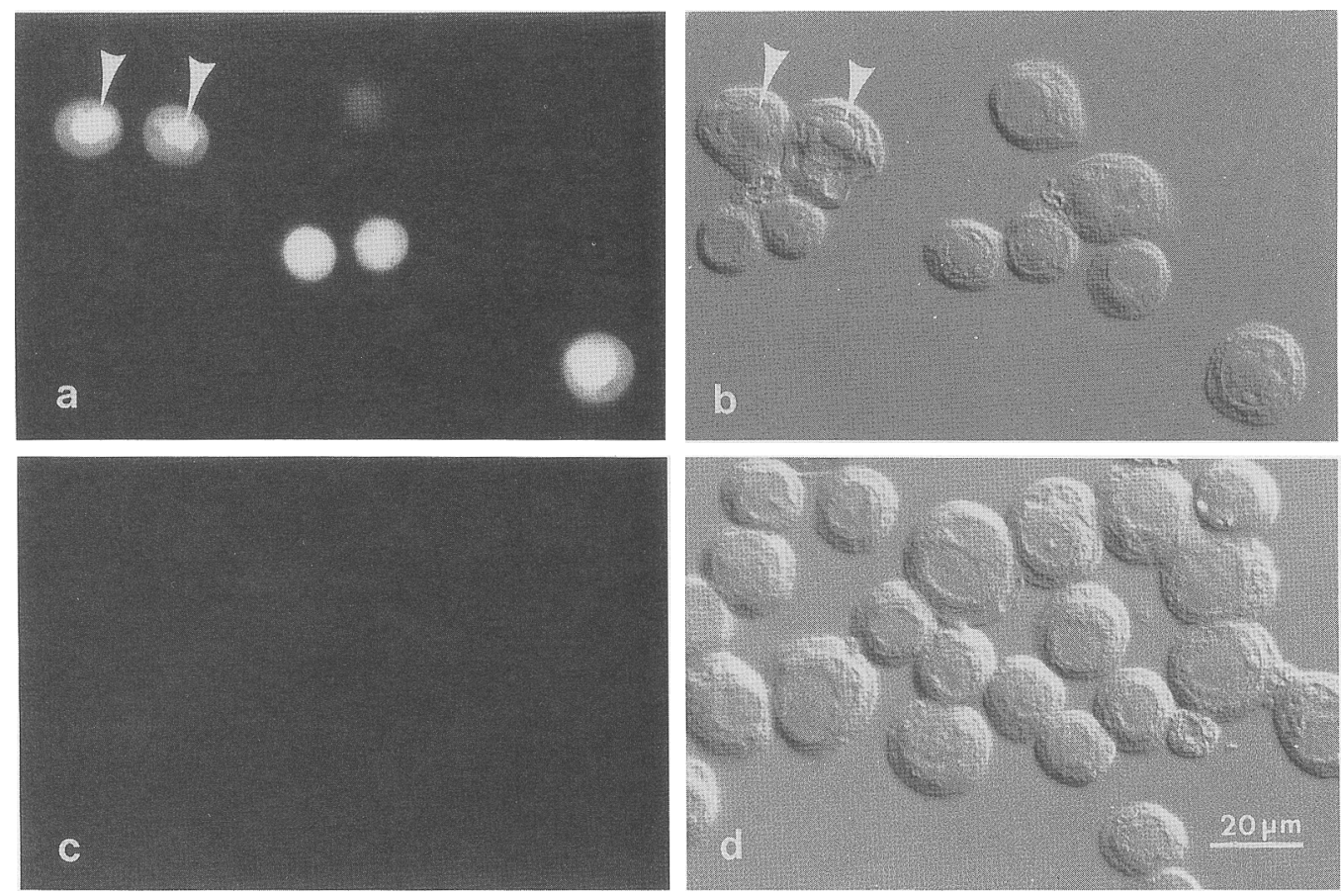

Figure 1. Hox-1.3 protein accumulates in the nuclei of $S$. frugiperda cells infected with the recombinant baculovirus. Immunofluorescence and differential interference contrast microscopy (DIC) views $\langle a, b)$ of host cells $20 \mathrm{hr}$ postinfection with a low multiplicity of infection. Note that Hox-1.3 protein colocalizes with intranuclear inclusions (arrowheads). Uninfected cells, immunostained with anti-Hox-1.3 $(c)$ or viewed by DIC $(d)$, show that they lack the Hox-1.3 epitope and contain no intranuclear inclusions. Cells infected with wild-type or unrelated recombinant viruses also show no immunostaining (data not shown).

faster migrating forms (Fig. 3b). Alkaline phosphatase treatment of the $\left.{ }^{35} \mathrm{~S}\right]$ methionine-labeled proteins substantiates the conclusion that phosphorylation was the principal factor in generating the multiple forms of the protein resolved by SDS-polyacrylamide gel electrophoresis. As shown in Figure 3C, treatment with alkaline phosphatase converts the slower migrating forms of the Hox-1.3 protein into the faster migrating form. Alkaline treatment alone (100 mM NaOH for $30 \mathrm{~min}$ ) does not alter the SDS-gel pattern (data not shown). Consequently, multiple phosphorylations, and not poly-ADP ribosylation, are responsible for the altered migration. Recently, Gay et al. (1988) reported that another homeo domain protein, the Drosophila engrailed protein, is also modified by phosphorylation.

\section{Differential extraction of the Hox-1.3 proteins from nuclei}

Western blot analysis of proteins extracted from NIH-3T3 nuclei with buffers containing different $\mathrm{NaCl}$ concentrations reveals that the multiple Hox-1.3 forms possess different avidities for the nuclear binding sites (Fig. 4B). Higher $\mathrm{NaCl}$ concentrations were required to efficiently extract the slower migrating forms. The same differential extraction was also observed in cultured embryonic fibroblasts, which maintained a significantly lower steady-state level of the Hox-1.3 protein (Fig. 4A). The comigration of the recombinant and the fibroblast Hox -1.3 forms suggests that the different endogenous forms represent differences in the level of phosphoryla- tion and that the differential salt extraction of Hox-1.3 proteins from nuclei of fibroblasts is a manifestation of the increased affinity of phosphorylated forms for nuclear factors.

\section{Hox-1.3 protein binds the promoter region of its own gene}

The protein-/DNA-binding studies of others have demonstrated that fusion proteins containing homeo domains and full-length unmodified homeo domain proteins bind DNA in a sequence-specific manner (Desplan et al. 1985; Fainsod et al. 1986; Cho et al. 1988; Hoey and Levine 1988). Furthermore, genetic studies of Drosophila homeo box genes have provided evidence that they regulate their own expression, as well as the expression of other homeo box genes (for review, see Gehring 1987). These activities are presumed to depend on the homeo domain proteins' ability to bind to the cis-acting elements controlling these genes. To determine whether the Hox-1.3 gene product also binds to the $5^{\prime}$ region of its own gene, we performed DNase I protection analyses. Depending upon the amount of the recombinant Hox -1.3 protein added in the assay (1.2-9.6 $\mu \mathrm{g}$ of total protein), different regions of the $5^{\prime}$ sequences were protected (Fig. 5). The sequence $a-b$ was protected with the least amount of extract, whereas the adjacent sequences ( $c$ and d) required eight times more extract to obtain significant protection /under the conditions of our assay, the $\mathrm{a}-\mathrm{b}$ footprint was also detected with 0.4 $\mu \mathrm{g}$ of extract). None of these footprints was detected 


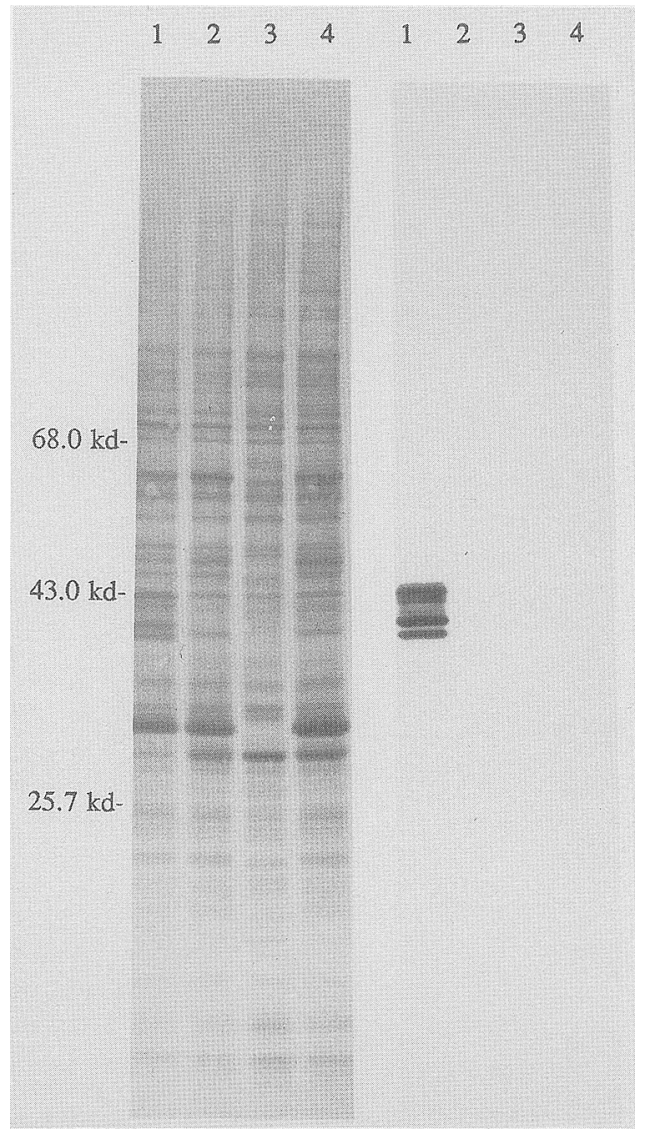

Figure 2. Immunoblot analysis of nuclear extracts demonstrates that Hox-1.3 immunoreactive proteins are unique to extracts from cells infected with the Hox-1.3 recombinant virus. Nuclear extracts were prepared according to the Dignam et al. (1983) protocol from Hox-1.3 recombinant virus infected cells (36 hr) (lane 1); wild-type baculovirus infected cells ( $36 \mathrm{hr}, \mathrm{PI}$ ) (lane 2), uninfected cells (lane 3), and unrelated recombinant virus-infected cells (36 hr, PI) (lane 4). Proteins $(\sim 10 \mu \mathrm{g})$ were resolved in a $12.5 \%$ polyacrylamide-SDS gel and electroblotted onto nitrocellulose. (Left half) Amido black staining; (right half) immunoblot with Hox-1.3 peptide-specific monoclonal antibodies. The same immunostaining profile was observed with a peptide-specific polyclonal antibody (data not shown).

when equivalent amounts of extracts not containing the Hox-1.3 protein were used (Fig. 5).

To confirm the specificity of the Hox-1.3 proteinDNA interaction and determine whether both phosphorylated and nonphosphorylated forms bind DNA, we carried out Southwestern analysis, using both specific and nonspecific double-stranded DNA probes (Fig. 6). The results of these experiments demonstrate that when separated by SDS-polyacrylamide gel electrophoresis and immobilized on nitrocellulose, all forms of the Hox-1.3 protein bind DNA in a sequence-specific manner. This indicates that the Hox-1.3 protein interacts directly with DNA by itself, and not with the aid of other nuclear factors.

The Hox-1.3 and Hox-2.1 (Krumlauf et al. 1987) homeo box genes are thought to have originated from a duplication event that included adjacent regions of the Hox-1 and Hox-2 homeo box gene clusters, located on murine chromosomes 6 and 11, respectively (Hart et al. 1987; Odenwald et al. 1987; Verrijzer et al. 1988). The observed similarity in the pattern of gene expression, in both embryonic and adult tissues, argues that the regulatory regions of these genes may exhibit considerable homology (for review of embryonic expression, see Holland and Hogan 1988). The putative promoter regions of these two genes contain multiple blocks of homologous sequences. One of these $5^{\prime}$ regions shares $68 \%$ homology (over a sequence of $33 \mathrm{bp}$ ) with the human immunoglobin heavy chain transcription enhancer (Rabbitts et al. 1983) and corresponds to sequences contained in the $\mathrm{c}$ and d footprints (Fig. 7). Multiple copies of sequences found in the b footprint are also part of the immunoglobin enhancer. The Hox $-1.3 \mathrm{a}-\mathrm{b}$ protected sequence shares homology with footprints obtained with other homeo domain fusion proteins or full-length recombinant proteins (Cho et al. 1988; Hoey and Levine 1988). Footprints $c$ and $d$ (Figs. 5 and 7) do not share homology with each other or with the $a-b$ footprint.

The specificity of the Hox-1.3 protein-DNA binding was further investigated using an electrophoretic mobility shift assay and end-labeled synthetic DNA fragments. Incubation of a 30-bp segment of DNA corresponding to the $\mathrm{a}-\mathrm{b}$ footprint sequence (Table 1), with Hox-1.3-containing extract, resulted in the formation of multiple complexes (Fig. 8A). The addition of the monoclonal 1D-9 antibody to the binding reaction revealed (via altered complex migration) that $H o x-1.3$ protein was associated with the faster migrating complexes. These complexes were not detected when extracts prepared from uninfected or wild-type baculovirus-infected cells were used (data not shown). Competition experiments with an unlabeled, unrelated control 30-bp fragment (Table 1) indicated that the other complexes, unaffected by the Hox-1.3 antibody, were the result of nonspecific binding (Fig. 8A). Increasing the poly[d(I-C)] concentration fourfold also blocked the nonspecific binding without altering the formation of Hox-1.3 protein-DNA complexes (Fig. 8B,C). The formation of Hox-1.3 associated complexes was not influenced when unlabeled control DNA was included in the binding buffer but was blocked when the unlabeled specific DNA fragments were included in competition experiments (Fig. 8C). Because polyacrylamide gel percentages $\geqslant 8 \%$ were necessary to resolve the individual Hox-1.3 protein-DNA complexes, it is unlikely that the changes in mobilities are due to multimerization. Rather, it suggests that some secondary alteration in the protein's conformation (perhaps induced by phosphorylation) may account for the different mobilities of the protein-DNA complexes. Mobility shift assays designed to examine the effect of monovalent salt concentrations on the Hox-1.3 proteinDNA binding revealed that although binding was detected in the presence of $800 \mathrm{~mm} \mathrm{KCl}$, the formation and/or stability of the faster migrating complexes were selectively diminished in higher salt concentrations (Fig. 9). The selective retention of the slower migrating forms 


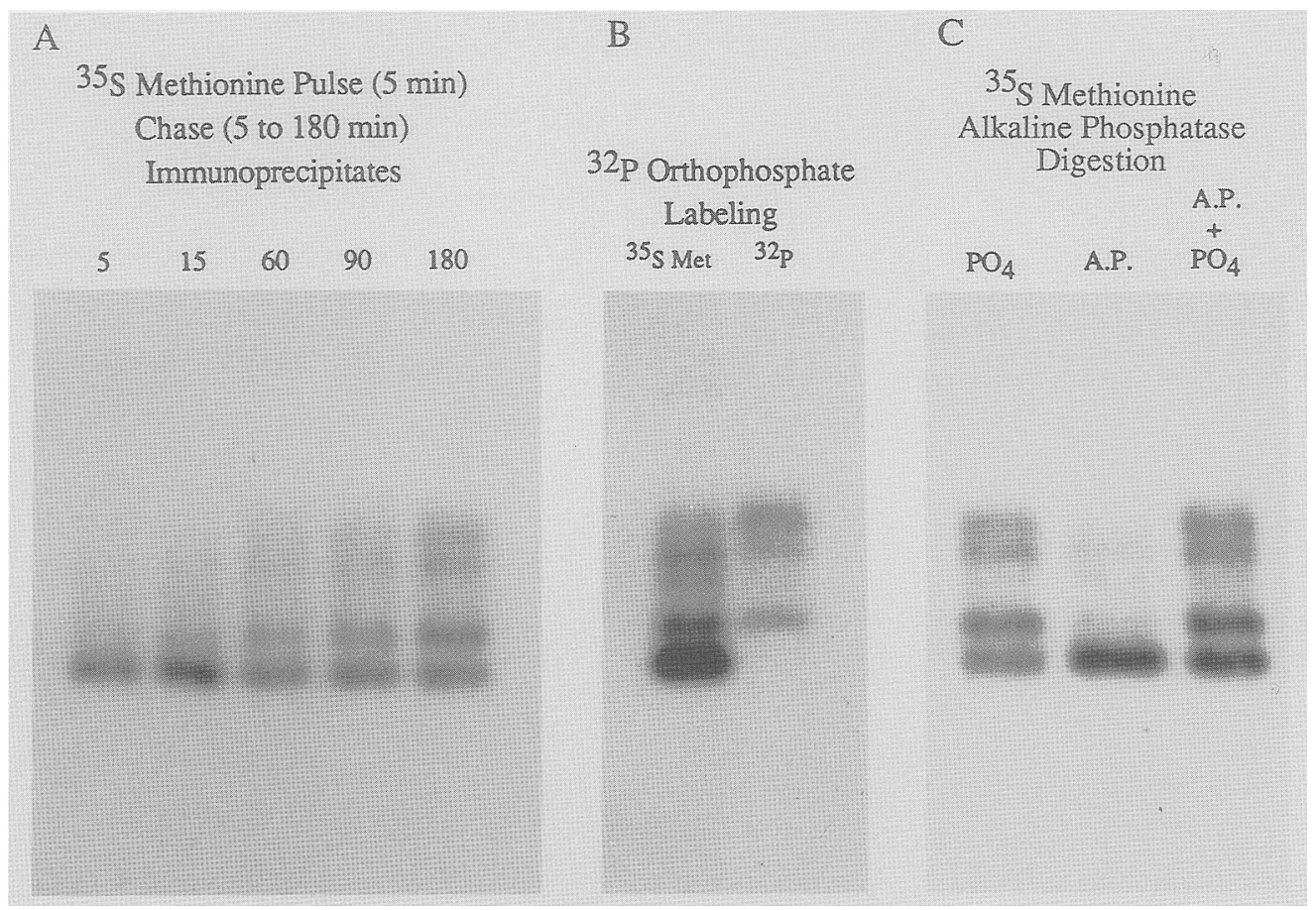

Figure 3. Multiple phosphorylation events alter the mobility of Hox-1.3 in polyacrylamide-SDS gels. $(A)$ Pulse-chase experiments reveal that multiple immunoreactive Hox-1.3 proteins arise from the fastest migrating form. $(B)$ Comparison of $\left[{ }^{35} S \mid m e t h i o n i n e-\right.$ and [22]orthophosphate-labeled Hox-1.3 immunoprecipitated proteins demonstrates that the slower migrating forms of Hox-1.3 are phosphoproteins. $(C)$ Disappearance of the Hox-1.3 phosphoproteins after treatment with alkaline phosphatase suggests that their slower mobilities are due to phosphorylation. $\left(\mathrm{PO}_{4}\right), \mathrm{Hox}-1.3$ recombinant $\left[{ }^{35} \mathrm{~S}\right]$ methionine-labeled extract preincubated with $200 \mathrm{mM} \mathrm{NaPO}_{4}$ buffer ( $\mathrm{pH} 8.0$ ) before immunoprecipitation; (A.P.) extract preincubated with E. coli alkaline phosphatase; (A.P. $\left.+\mathrm{PO}_{4}\right)$, as A.P. but in the presence of $200 \mathrm{mM} \mathrm{NaPO}_{4}$ buffer (pH 8.0) to demonstrate that the disappearance of the Hox-1.3 phosphoproteins in A.P. is not due to proteolysis.

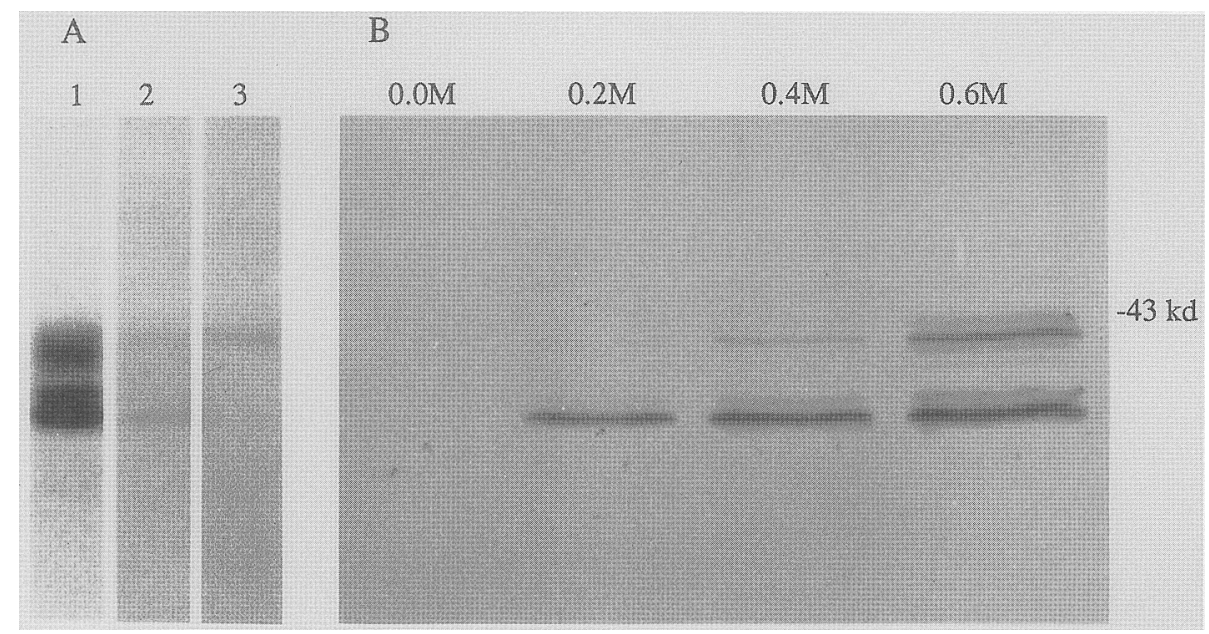

Figure 4. Differential salt elution of nuclear Hox-1.3 proteins from cultured mouse embryo cells and NIH 3 T3 fibroblasts. $(A)$ Autoradiographs of $\left[{ }^{35} \mathrm{~S}\right]$ methionine-labeled immunoprecipitated proteins resolved in a $12.5 \%$ polyacrylamide-SDS gel. (Lane 1 ), Hox-1.3 recombinant proteins (autoradiographic exposure time, $48 \mathrm{hr}$ ), (lane 2), Hox-1.3 immunoreactive proteins present in a $600 \mathrm{~mm}$ $\mathrm{NaCl}$ wash of nuclei from cultured mouse primary embryonic fibroblasts (exposure, 3 weeks); (lane 3), Hox-1.3 immunoreactive proteins present in these nuclei after the $600 \mathrm{~mm} \mathrm{NaCl}$ wash, solubilized by RIPA buffer (exposure, 3 weeks). Note the comigration of the fibroblast proteins with those of the recombinant. Also note that a significant amount of the slower migrating (presumably phosphorylated) protein is not eluted from the nuclei during the $600 \mathrm{~mm}$ salt wash. $(B)$ Nuclei prepared from nonconfluent $3 \mathrm{~T} 3$ fibroblasts were aliquoted and exposed to one of four different $\mathrm{NaCl}$ concentrations. The proteins in these salt washes were resolved in a $12.5 \%$ SDS-polyacrylamide gel, electroblotted onto nitrocellulose, and immunostained with Hox-1.3-specific antibodies. The observed differential elution profile of the Hox-1.3 proteins suggests that the slower migrating forms may have a higher affinity for nuclear binding sites. 


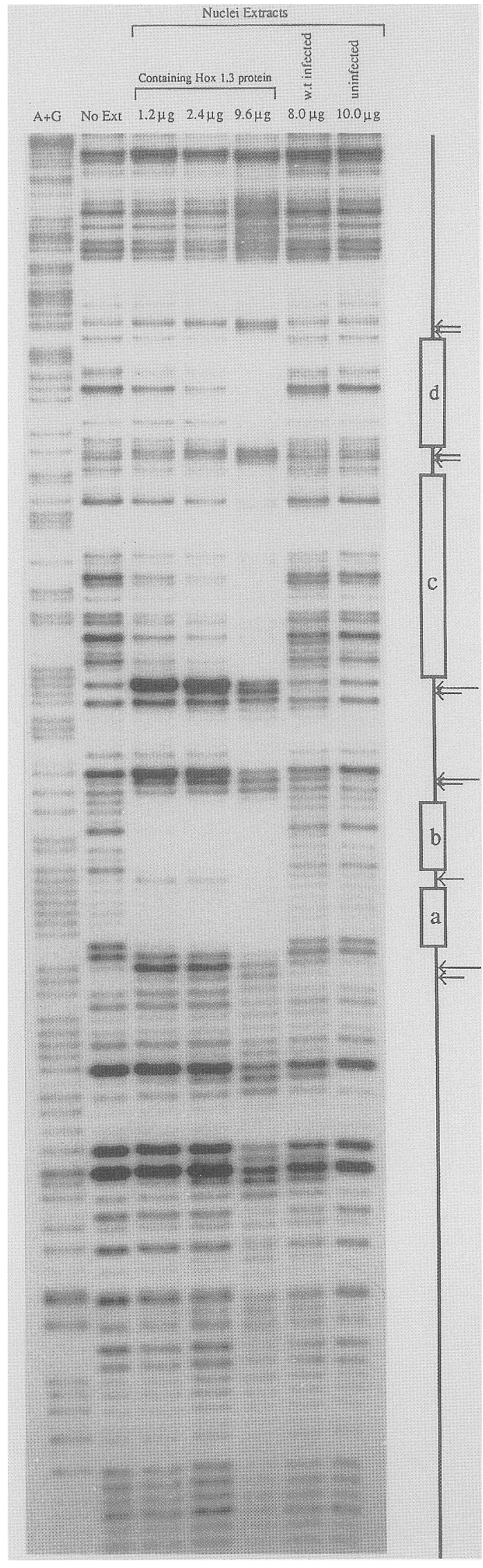

indicates these DNA-protein complexes were more stable. These observations and the relative resistance of the phosphorylated forms of Hox-1.3 to salt extraction from isolated nuclei (Fig. 4) strengthen the notion that the multiple complexes may arise by phosphorylation of the Hox-1.3 protein.

To footprint regions $\mathrm{c}$ and $\mathrm{d}$, greater amounts of extract were required when compared to the $a-b$ footprint. However, the $\mathrm{c}$ and $\mathrm{d}$ footprints were specific for the extract containing the Hox-1.3 protein, indicating that either Hox-1.3 protein can bind these sequences, albeit with lower affinity, or other DNA-binding proteins in the extract can interact in a cooperative manner with Hox-1.3 to bind adjacent sequences. The lack of shared sequence homology between these different footprints and the inability of a 30 -bp fragment containing the footprint c sequence to compete for Hox-1.3 binding (Fig. $8 \mathrm{C}$ ) argue in favor of the latter. Distinction between these two possibilities and the role of phosphorylation await the purification of the individual Hox-1.3 isoforms.

\section{Hox-1.3 protein requires an ATTA box for efficient binding}

To determine those base pairs necessary for efficient Hox-1.3 binding, we carried out a series of mobility shift assays with different synthetic 30 -bp oligonucleotides that share partial homology with the a-b Hox-1.3 footprinted sequence (Fig. 8B,C; summarized in Table 1). Assays were also performed to test whether Hox-1.3 protein-binding sites (predicted by sequence homology) existed in the promoter regions of other homeo box genes and in well-characterized cis-regulatory elements of other non-homeo-box genes (Fig. 8; Table 1). The results of these assays highlight the importance of the core 5'ATTA-3' for efficient Hox-1.3 binding. Single base alterations in the core ATTA box significantly reduce or abolish detectable binding under the conditions of our assays (see Methods and legend to Fig. 8). The lack of demonstrable Hox-1.3 binding to the mHox 1.3e oligonucleotide (ATTA $\rightarrow$ AAAT; Table 1) further indicates that $H o x-1.3$ protein interacts in a selective, sequencespecific manner with the ATTA sequence and does not bind indiscriminately to AT-rich sequences. Overlapping ATTA boxes in both orientations, 5'-TAATTA-3', also represent a high affinity core recognition sequence,

Figure 5. DNase I protection analysis of the Hox-1.3 promoter region. A 310bp genomic fragment that contains $250 \mathrm{bp}$ of $H o x-1.3$ upstream sequences from the $5^{\prime}$ cap site of the major transcript was employed (see Fig. 6 and Methods). (A + G) Maxam and Gilbert purine ladder. (No Ext) DNase-I digest of $\sim 1 \mathrm{ng}$ of end-labeled DNA after incubation with $1.0 \mu \mathrm{g}$ poly[d (I-C)], in reaction to buffer containing $200 \mathrm{mM} \mathrm{KCl}$ and no nuclear extract. Amounts of $1.2,2.4$, and $9.6 \mu \mathrm{g}$ of the Hox-1.3 protein-containing nuclear extract were preincubated with the end-labeled fragment, as above, prior to DNase I treatment. Nuclear extracts from wild-type virus-infected $(8.0 \mu \mathrm{g})$ and uninfected $(10.0 \mu \mathrm{g})$ were also tested. In the flanking cartoon, boxes represent protected regions and arrows indicate DNase-I hypersensitive sites induced by the Hox-1.3-containing extract. Note that protected regions $a$ and $b$ are detected in the digests that contain $1.2 \mu \mathrm{g}$ of extract, whereas regions $c$ and $d$ show significant protection only with $9.6 \mu \mathrm{g}$. 


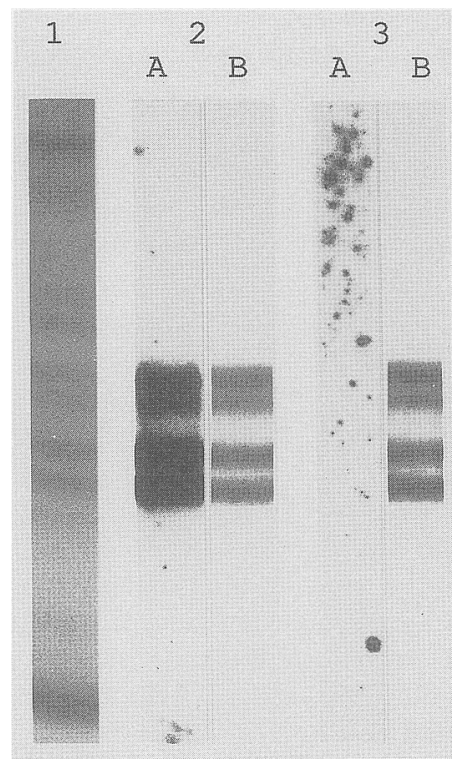

Figure 6. Both phosphorylated and nonphosphorylated Hox-1.3 proteins are sequence-specific DNA-binding proteins. Nuclear extract from Hox-1.3 recombinant virus-infected cells was fractionated electrophoretically through a $12.5 \%$ polyacrylamide-SDS gel and transferred to a sheet of nitrocellulose. This sheet was cut into individual strips, each of which contain separated proteins between apparent molecular weights of $\sim 27-60 \mathrm{kd}$. Adjacent strips were treated in the following way: (Strip 1) The amido black staining of the immobilized proteins. Strip 2 was probed with a radiolabeled, catenated DNA fragment containing multiple $a-b$ DNase-I-protected sequences (see Fig. 5 and Methods). After autoradiographic exposure (2A), immunoblot analysis of strip 2 was carried out to identify Hox-1.3 immunoreactive proteins (2B). Strip 3 was processed the same as strip 2 but probed with a radiolabeled concatemer that lacks the $a-b$ sequence (3A) (see Methods). (3B) The Hox-1.3 immunoblot of this strip. Note that all forms of the Hox -1.3 protein that are identified by the antibody bind DNA in a sequence-specific manner.

as detected in our mobility shift assays with the yeast alB-factor gene P-box cis-control element (Fig. 8C; Table 1). Our gel shift assays identified base pairs in the flanking sequences that enhanced or reduced binding. From these data, we compiled a consensus Hox-1.3 binding motif $\left(5^{\prime}\right.$-CPyPyNATTAT/GPy-3') that reflects the sequences present in the 'good' binding oligonucleotides (Table 1). As shown in Figure 10, this DNA-binding motif shares overlapping sequence homology with the DNA-binding motifs of both the DNA replication nuclear factor III (NF-III) (Pruijn et al. 1987; Rosenfeld et al. 1987) and the transcription factor AP-1/c-jun (Bohmann et al. 1987; Lee et al. 1987).

\section{Discussion}

Here we have combined high level expression of a recombinant murine homeo domain protein, Hox-1.3, DNase I footprint analysis, Southwestern protein-DNA binding, and electrophoretic mobility shift assays to characterize the DNA-binding specificity of the Hox-1.3 protein. Our studies highlight several features of the interaction of this homeo domain protein with its nuclear target(s). First, the Hox-1.3 recognition sequence is not unique to the Hox -1.3 gene. Closely related sequences are found in other homeo box gene promoters and in many other cis-regulatory elements, both viral and cellular. A comparison of these sequences tested for Hox-1.3 binding allowed us to deduce a consensus sequence, 5'-CPyPyNATTAT/GPy-3', with the core ATTA being required for efficient binding. Second, in certain cis-elements, this consensus sequence overlaps sequences recognized by well-studied transcription factors such as AP-l or the proteins binding to the octamer sequence. Third, post-translational modifications give rise to multiple $H o x-1.3$ forms distinguishable by their degree of phosphorylation, and these forms appear to display a characteristic binding avidity for nuclear factors. From these features, it is evident that the interaction of this homeo domain protein with its DNAbinding sites, if at all relevent in gene regulation, cannot be viewed separately from other systems of gene regulation; competition among different proteins for the same DNA target, binding of the same protein to related targets in different genes, and the regulation of the strength of binding to nuclear factors by post-translational modification all point to gene regulation, dependent upon control systems both highly integrated and well balanced. In the following text, we will discuss the points mentioned above.

\section{Determinants of Hox-1.3 protein-DNA binding}

All Antennapedia (Antp) class homeo domain proteins studied thus far recognize sequences sharing the ATTA core sequence (see references cited above). In Drosophila, all homeo domain footprints reported contain the core ATTA box, with the exception of the even-skipped and paired protein footprints of the even-skipped promoter region (Hoey and Levine 1988). Yet, even in the even-skipped e4 DNase I-protected region, the sequence 5'-CCTCGTTATC-3' matches the Hox-1.3 consensus sequence, except for 1 base, G. It is noteworthy in this context that substitution of GTTA for the core ATTA in an otherwise perfect consensus sequence still shows Hox-1.3 binding, albeit weak (see Fig. 8; Table 1). This DNA recognition sequence conservation may reflect no more than that the proteins' DNA-binding domain (the homeo domain) has also been conserved during evolution. For example, all Antp class homeo domains share homologous, if not identical, amino acid residues in the region thought to contact DNA (for review, see Gehring, 1987). If distinct homeo domain proteins bind to the same sequence and yet accomplish unique functions, domains not directly involved in DNA binding are likely to play an important role in this specificity. It is conceivable that such protein domains interact in very specific ways with other components of the transcriptional machinery.

The comparison in mobility shift assays of DNA fragments containing different $H o x-1.3$ binding sites has shown that the sequences flanking the ATTA box influ- 


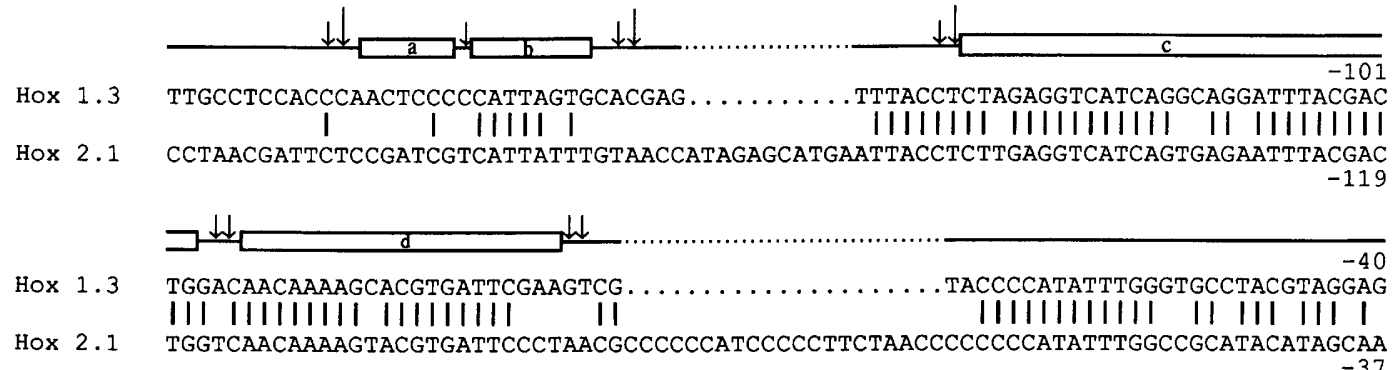

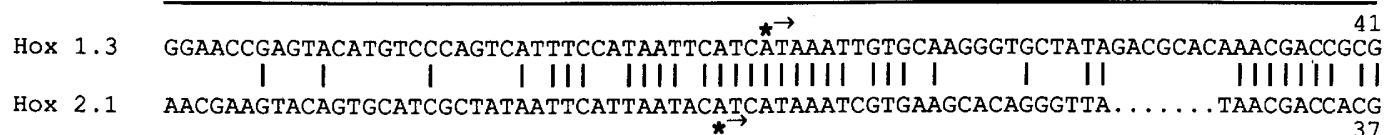

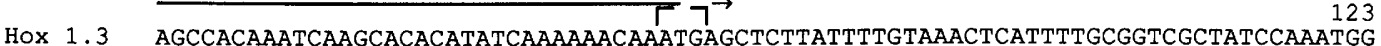

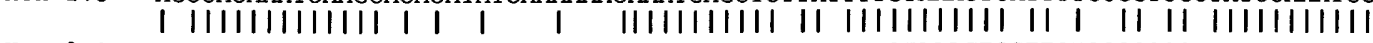

$\begin{aligned} \text { Hox } 2.1 \text { ATCCACAAATCAAGCCCTCCAAAATCACC. CAAATGAGCTCGTACTTTGTAAACTCCTTCTCGGGGCGTTATCCAAATGG } & 118\end{aligned}$

Figure 7. Alignment of Hox-1.3 DNase I footprints with upstream homologies between the Hox-1.3 and Hox-2.1 genes. Optimal alignment of Hox-1.3 (Odenwald et al. 1987) and Hox-2.1 (Krumlauf et al. 1987) upstream sequences reveals blocks of noncollinear homologies. One of these regions (Hox-1.3, - 109 to -77 ; Hox-2.1, -127 to -95 ) shares $68 \%$ sequence homology with a human Ig germ line heavy chain enhancer element (Rabbitts et al. 1983). Note that this region is coincident with DNase-I-protected regions $c$ and $d$. Sequences homologous to protected region $b$ (ATTA) are also present in multiple copies in the heavy chain enhancer element (see Rabbitts et al. 1983). Adult lung Hox-1.3 and Hox-1.2 mRNA major cap sites (Murphy et al. 1988; R. Krumlauf, unpubl.) are denoted by stars; translation start codons are bracketed.

Table 1. Summary of protein-DNA binding studies

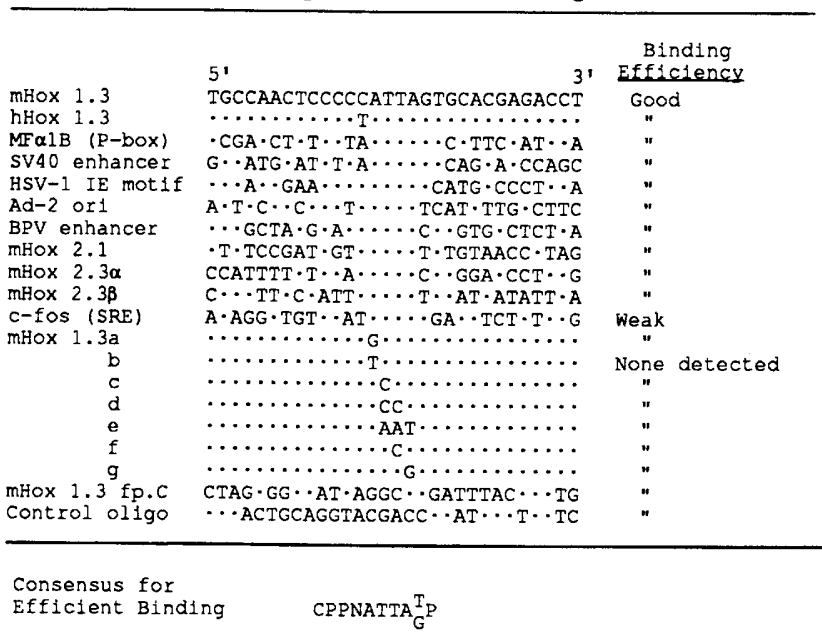

Electrophoretic mobility shift assays were performed on the above double-stranded end-labeled 30-bp oligonucleotides (sequence of one strand shown). (mHox-1.3) Sequence contains a-b footprint shown in Fig. $7(-160$ to $-137 \mathrm{bp}$ ); (hHox-1.3) corresponding $\mathrm{mHox}-1.3$ sequences present in the human Hox-1.3 cognate promoter region (E. Tournier et al., unpubl.); [MF $\alpha 1 \mathrm{~B}$ (P-box)] yeast $\alpha$-factor structural gene $\alpha 1 \mathrm{~B}$ cis-control region $(-366$ to $-341 \mathrm{bp})$ contains the P-box (Bender and Sprague 1987; binding data not shown); (SV40 enhancer) domain A, P motif (Zenke et al. 1986); (HSV-1 IE motif) motif of $\alpha$ gene $O$ promoter region $(-236$ to $-207 \mathrm{bp}$; Mackem and Roizman 1982); (Ad-2 ori) adenovirus-2 origin of DNA replication (58-31 bp; Wides et al. 1987); (BPV enhancer) bovine papilloma virus long control region enhancer (7590-7612 bp; Mos- ence the strength with which the Hox-1.3 proteins bind to DNA. DNA recognition sequence comparisons of the different homeo domain protein-binding sites indicate that although the ATTA box is shared, individual proteins may require unique flanking sequences for high-affinity binding.

The degree of protein phosphorylation also appears to affect binding avidity to unknown nuclear components. At present, it is unclear whether this post-translational modification influences DNA binding, protein-protein interactions, or both. Nevertheless, when multiple DNA-binding sites with different binding avidities are available, the intranuclear concentrations of these proteins and their phosphorylation status are likely to play significant roles in modulating gene expression. Recent studies in Drosophila point in this direction. For instance, the bicoid homeo domain protein influences cell differentiation in a concentration dependent manner (Driever and Nüsslein-Volhard 1988).

kaluk and Bastia 1988); (mHox-2.1) murine Hox-2.1 promoter region (-191 to $-163 \mathrm{bp}$; Fig. 7 and Krumlauf et al. 1987); (mHox-2.3 $\alpha, \mathrm{mHox}-2.3 \beta$ ) murine Hox-2.3 gene promoter region $(\alpha, 799-806 \mathrm{bp} ; \beta, 730-756$ bp; Verrijzer et al. 1988); [c-fos [SRE)] serum response element in the c-fos enhancer $(-319$ to $-269 \mathrm{bp}$; Treisman 1985); (mHox-1.3a through mHox-1.3g) variations of $\mathrm{mHox}-1.3$; ( $\mathrm{mHox}-1.3 \mathrm{fp} . \mathrm{c}$ ) ) the $\mathrm{c}$ footprint shown in Fig. $7(-128$ to -99 bp). Dots represent identity with $\mathrm{mHox}-1.3$. The relative binding efficiency represents an arbitrary assessment based on autoradiographic signal intensity comparisons between free and bound DNA (Fig. 8) (P) Pyrimidine; $(\mathrm{N})$ any base. 


\section{Odenwald et al.}

Occurrence of the Hox-1.3 binding motif in promoter regions of other genes

As shown above, not only does Hox-1.3 bind to sequences in its own gene and those of other homeo box genes, it also recognizes related sequences known to be to one or several host factors that bind to the IE cis-ele- ment themselves (Kristie and Roizman 1987). Because both Hox-1.3 (Fig. 7B) and these host factors recognize similar DNA sequences and recognize them independently of Vmw65, it is tempting to speculate that they are homeo domain proteins. Another example is found regulatory elements of other genes. Some of them are worth mentioning. To stimulate expression of the im-

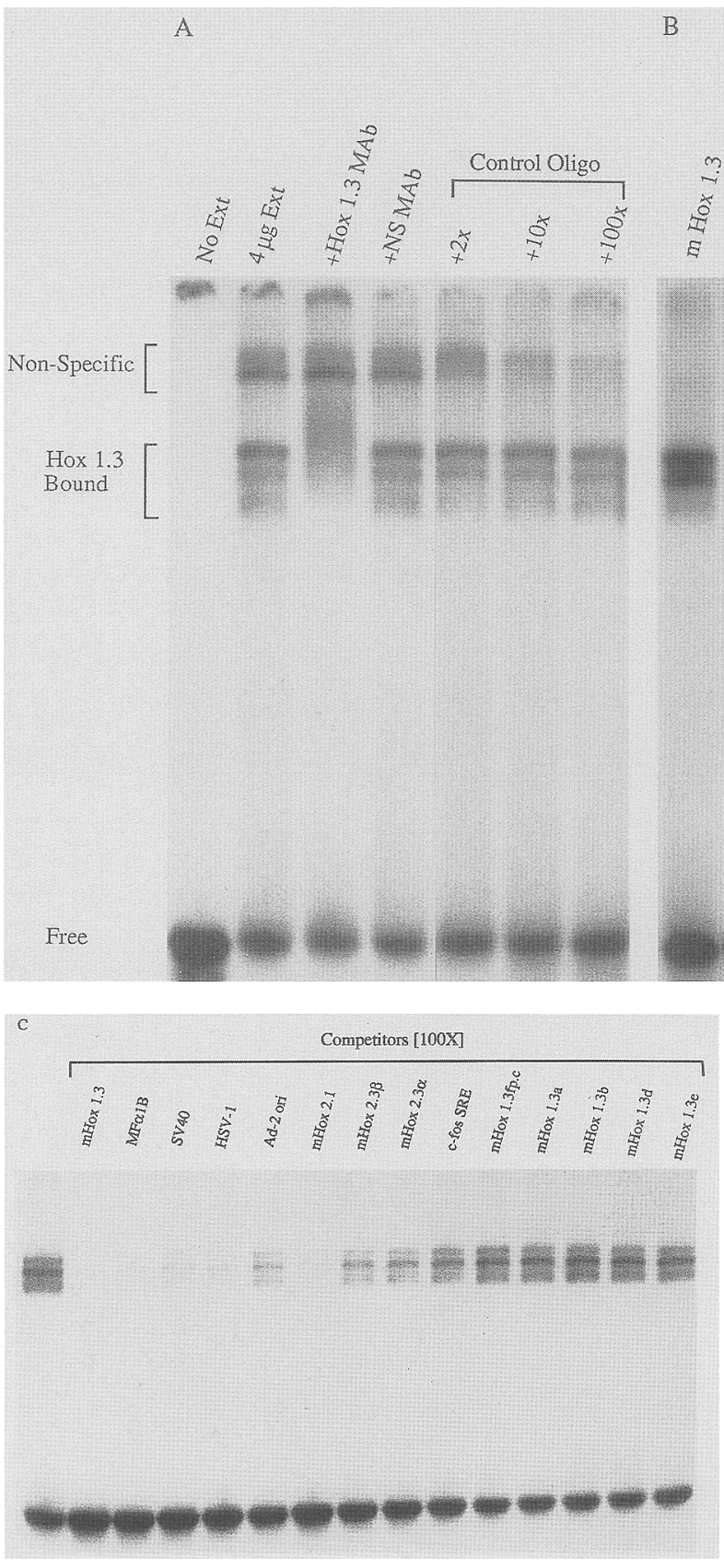

Figure 8. Cis-regulatory elements that control both transcription and DNA replication contain Hox-1.3 protein-binding sites. $(A)$ An end-labeled 30-bp synthetic DNA fragment (mHox-1.3; see Table 1) that contains the putative Hox-1.3 protein-binding site was employed to both confirm Hox-1.3 protein binding (via specific antibody interaction altering the mobility of the protein-DNA complexes/ and to determine conditions that favor only sequence-specific binding. In a native $9.5 \%$ polyacrylamide gel, multiple-bound complexes are resolved from a binding reaction with $4 \mu \mathrm{g}$ (total protein) of extract-containing recombinant Hox-1.3 protein, 0.5-1.0 ng of $\left[\alpha^{-32} \mathrm{P}\right]$ end-labeled $\mathrm{mHox}-1.3$ fragment $\left(2 \times 10^{4} \mathrm{cpm}\right)$ and $1 \mu \mathrm{g}$ of poly[d(I-C)] (lane $4 \mu \mathrm{g} \mathrm{Ext).} \mathrm{An} \mathrm{additional} \mathrm{incubation} \mathrm{(after}$ complex formation) with ascites fluid containing Hox-1.3-specific monoclonal IgG antibodies (final ascites dilution 1-100) reveals that the Hox-1.3 protein associates with the faster-migrating complexes (lane Hox-1.3 MAb). Incubation with an unrelated monoclonal IgG did not alter complex migration (lane NS MAb). Competition with an unlabeled 30-bp control oligonucleotide (Table 1) revealed that the slower-migrating complexes are the result of nonspecific interactions (lanes $+2 \times,+10 \times$, and $+100 \times)$. Increasing the poly[d(I-C)| to $4 \mu \mathrm{g} /$ reaction also diminished these nonspecific complexes (see Fig. 8B,C). (B) End-labeled synthetic 30-bp fragments shown in Table 1 were employed to determine the sequence specificity of Hox-1.3 binding. Complex formation was performed in the presence of $4 \mu \mathrm{g}$ (total protein) of Hox-1.3-containing extract, $4 \mu \mathrm{g}$ of poly[d(I-C)], $0.5-1 \mathrm{ng}$ of end-labeled oligonucleotide $\left(2 \times 10^{4} \mathrm{cpm}\right)$, and $200 \mathrm{mM} \mathrm{KCl}$ in $20 \mu \mathrm{l}$ of binding buffer. $(C)$ Competition analysis comparing Hox-1.3 protein-DNA binding between individual unlabeled oligonucleotides (Table 1) and labeled $\mathrm{mHox}-1.3$ fragment. One-hundred-fold excesses (as determined by optical density measurements) of the unlabeled fragments were mixed with the labeled $\mathrm{mHox}-1.3$ oligonucleotide in binding buffer prior to the addition of the Hox-1.3-protein-containing extract. 


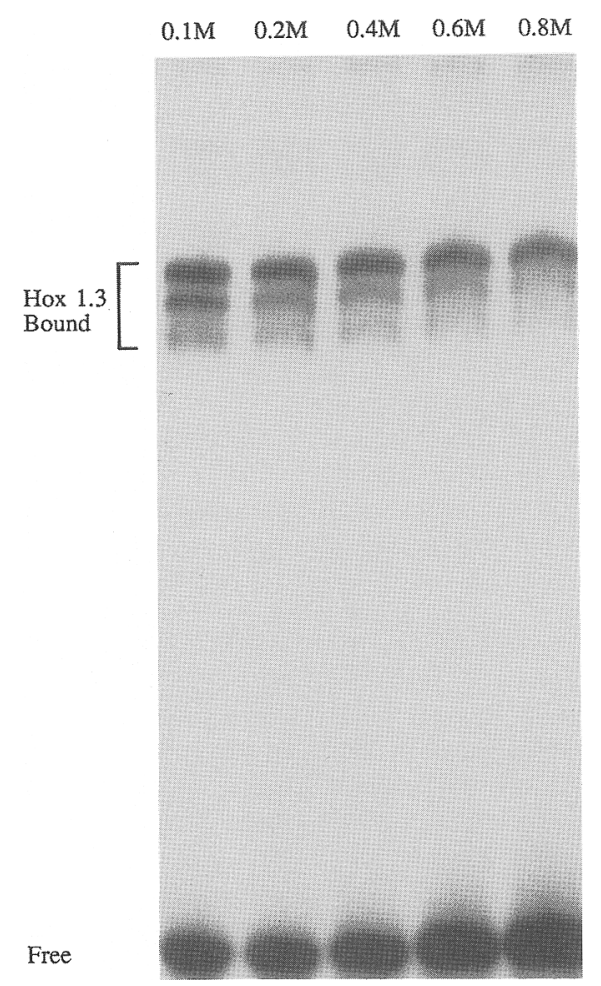

Figure 9. Differential Hox-1.3 protein-DNA complex affinities. Protein-DNA complexes between $H o x-1.3$ proteins $(4 \mu \mathrm{g}$ of total extract) and the end-labeled $\mathrm{mHox}-1.3$ double stranded oligonucleotide (shown in Table 1) were formed at $4^{\circ} \mathrm{C}$ for $1 \mathrm{hr}$ in binding buffer containing $4 \mu \mathrm{g}$ poly[d(I-C)] and either $0.1,0.2$, $0.4,0.6$, or $0.8 \mathrm{M} \mathrm{KCl}$. Complexes were resolved by electrophoresis through a $9.5 \%$ polyacrylamide gel. Note that in addition to causing an overall reduced electrophoretic mobility, the higher salt concentrations selectively reduced the formation and/or stability of the faster migrating complexes.

mediate early (IE) genes of herpes simplex virus (HSV), a viral protein, Vmw65 (also known as VP16) (Preston et al. 1988; Triezenberg et al. 1988), is required. Interestingly, this protein does not bind DNA directly but binds in yeast: The $\alpha$-specific upstream activating sequence P-box consensus (Bender and Sprague 1987) shares perfect homology with the Hox-1.3 motif. Activation of the $\alpha$-specific genes depends on the cooperative interaction of two factors, the pheromone response transcription factor (PRTF), which footprints the consensus motif (Bender and Sprague 1987), and the MATa1 factor. Because PRTF protects sequences that match the Hox-1.3 consensus binding motif, it is possible that this factor's DNA-binding element, as well, shares homology with the Hox-1.3 DNA-binding domain.

Potential homeo domain binding sites also occur within origins of DNA replication. DNA sequences that function as autonomously replicating sequences (ARS) within yeast contain potential homeo domain binding sites. For example, elements within the yeast ARS- 120 (Eisenberg et al. 1988) and ARS-C2Gl (Palzkill and Newlon 1988) and the human ARS-2 (Montiel et al. 1984) all contain multiple sites that share homology with the Hox-1.3 binding motif. In addition, the origins of DNA replication of adenovirus (Wides et al. 1987),
Optimal Alignment of Transcription Factor Binding Motifs

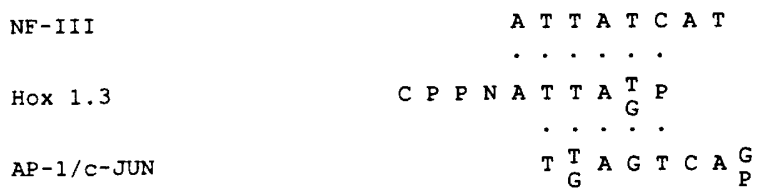

Figure 10. Overlap among transcription factor DNA-binding motifs. Alignment of NF III, an octamer binding protein (Pruijn et al. 1987; Rosenfeld et al. 1987); Hox-1.3 (this paper); and AP-1/c-jun (Bohmann et al. 1987; Lee et al. 1987) DNA-binding motifs in $5^{\prime} \rightarrow 3^{\prime}$ alignment. (P) Pyrimidine; (N) any base.

HSV (Weller et al. 1985; Elias and Lehmann 1988), and Epstein-Barr virus (Rawlins et al. 1985; Reisman et al. 1985) contain multiple potential homeo domain binding sites. Many of these recognition sequences are contained within or overlap footprints by cellular or viral factors (see the above references for footprinting data). Although the functional significance of this observation is unknown, other transcription factors such as NF-1 (Jones et al. 1987; Santoro et al. 1988) and NF-III (Pruijn et al. 1987; Rosenfeld et al. 1987) have been shown to modulate in vitro DNA replication.

\section{Overlap of the Hox-1.3 motif with binding sites for other transcription factors}

Analysis of eukaryotic cis-regulatory elements reveals that the Hox-1.3 binding site can overlap with either AP-1 or octamer binding sites. Our DNase-I protection studies and electrophoretic mobility shift assays show that Hox-1.3 proteins bind efficiently in the absence of these transcription factor binding motifs, demonstrating the uniqueness of the Hox-1.3 motif. In the SV40 enhancer, our mobility shift assays identify a high-affinity Hox-1.3 protein-binding site within the SphI/P motifs of domain A (Zenke et al. 1986). This binding site (shown in Table 1) matches the Hox-1.3 consensus motif and overlaps both the Octa-2 (OBP100 protein-binding site, Sturm et al. 1987) and the AP-1 binding motif (Angel et al. 1987; Lee et al. 1987). Potential homeo domain binding sites also overlap with other AP-1 motifs in the SV40 genome (Lee et al. 1987). Many of the octamer binding sites in the $5^{\prime}$-flanking regions of immunoglobulin genes overlap or are adjacent to potential Hox-1.3 target sequences. Of the 20 octamer-containing Ig promoter regions shown by Parslow et al. (1984), 12 also harbor potential homeo domain binding sites of which 9 overlap with octamer motifs. The observed overlap of binding motifs for different classes of binding factors (highlighted in Fig. 10) raises the possibility that overlap in binding motifs may result in binding competition or cooperativity among different transcription factors, with the consequence that the activity of a particular transcription factor is not only determined by its own binding characteristics but also by those of others. Such mutual control among transcription factors may represent an important mechanism, by which a high number 
of different genes may be coordinately regulated by a lower number of transcription factors.

In conclusion, we have shown that a mammalian homeo domain protein (Hox-1.3) binds DNA in a sequence-specific manner and recognizes regulatory sequences in defined cis-elements. It is likely, then, that this homeo domain protein can play an important role in the regulation of other genes, both cellular and viral.

\section{Methods}

\section{Production of the recombinant Hox-1.3 baculovirus}

Baculovirus shuttle vector constructions were produced by using the pUC-Xho-rhomeo plasmid (obtained from S. Murphy and E. Linney, Duke University/ and the Autographa californica nuclear polyhedrosis virus (AcNPV) shuttle vector pAcYM-1 (Matsuura et al. 1986). An 847-bp XhoI-Scal fragment from pUC-Xho-rhomeo that contains a 14-bp synthetic linker, followed by the Hox-1.3 translation initiation codon and the entire $H o x-1.3$ protein-encoding sequence plus 18 -bp of $3^{\prime}$ untranslated sequence (Odenwald et al. 1987) was cloned into the BamHI site of pAcYM-1 by filling in $5^{\prime}$ protruding ends with the Klenow enzyme and dNTPs; blunt-end ligations followed, according to the procedures outlined by Maniatis et al. (1982).

The protocols of Summers and Smith (1987) were used for the care and propagation of both the AcNPV and its host, the $S$. frugiperda cells. After calcium phosphate cotransfection of the AcNPV genome and pAcYM-1-Hox-1.3 DNAs into $S$. frugiperda cells, transfer of the hybrid polyhedrin-Hox-1.3 gene into the viral genome was accomplished by double homologous recombination. The transfection protocol of Smith et al. (1983) was used. The procedures used for selecting, purification, and titering of the recombinant virus were carried out as described by Summers and Smith (1987).

\section{Cultured cells and nuclear extracts}

Mouse embryo cells were prepared according to Arnheiter and Staeheli (1983) from 16-day gestation BALB/c embryos. Experiments were performed on culture passages $4-6$. These embryo cultures and the NIH-3T3 mouse fibroblast cell line were maintained in DMEM containing $10 \%$ FCS and antibiotics. $S$. frugiperda cells were maintained in Grace's medium supplemented with lactalbumin hydrolysate $(3.3 \mathrm{~g} / \mathrm{liter})$, Yeastolate (DIFCO Labs) (3.3 g/liter), 10\% FCS, and antibiotics. Care and maintenance of the $S$. frugiperda cells was according to Summers and Smith (1987).

Nuclear extracts were prepared according to the procedure described by Dignam et al. (1983) from subconfluent monolayers of uninfected cells and infected $S$. frugiperda cells $36 \mathrm{hr}$ after virus absorption. Unless otherwise stated (see figure legends), nuclei were extracted in buffer D containing $100 \mathrm{~mm}$ Tris- $\mathrm{HCl}$ (pH 7.9), $600 \mathrm{mM} \mathrm{NaCl}, 5 \%$ glycerol, $5 \mathrm{mM} \mathrm{MgCl}_{2}, 1$ mM DTT and $1 \mathrm{~mm}$ EDTA. Final extract protein concentrations varied from 1 to $2 \mathrm{mg} / \mathrm{ml}$ (as determined by a Bio-Rad protein assay kit with BSA as a standard).

\section{Peptide synthesis}

A 20 -amino-acid-long peptide, corresponding to $H o x-1.3$ protein residues 56-75 (Odenwald et al. 1987), was synthesized by the Merrifield solid-phase technique (Merrifield and Barany 1980) with an Applied Biosystems 430-A peptide synthesizer. The 20 -mer was purified to a single peak by high pressure liquid chromatography, and the molecular weight and purity confirmed by mass spectrophotometry. Hydrolysis of the peptide gave amino acid compositions consistent with the expected ratios. The peptide was coupled to keyhole limpet hemocyanin (KLH) by procedures described previously (Odenwald et al. 1987).

\section{Monoclonal IgG production, Western immunoblot analysis,} and immunofluorescence

The mouse monoclonal 1D-9 IgG antibody that binds the 20mer synthetic peptide described above was produced following standard procedures (Amheiter et al. 1981). Supernatant fluids of cell cultures containing hybridomas were screened by the enzyme-linked immunoadsorption assay (ELISA), according to the protocol described by Richardson et al. (1985). The thricecloned (by limiting dilution) 1D-9 hybridoma was injected into the peritoneal cavity of female BALB/c mice for the production of ascitic fluid. Immunoblot analysis of both recombinant Hox-1.3 baculovirus infected $S$. frugiperda cell nuclei or cultured mouse fibroblast nuclei extracts using the 1D-9 monoclonal or rabbit polyclonal anti-peptide $\mathrm{A}$ antisera were done as described (Odenwald et al. 1987) and gave similar results. Likewise, the immunofluorescent labeling, also performed as described (Odenwald et al. 1987), with either antibody was similar. As control antibody, the monoclonal anti-peptide IgG III/21 (Arnheiter et al. 1981) was used.

\section{Radiolabeling, alkaline phosphatase digestion, and immunoprecipitations}

Radiolabeling of recombinant infected $S$. frugiperda cells $(36 \mathrm{hr}$ post virus adsorption) with either $\left[{ }^{35} S\right]$ methionine or carrierfree [ $\left.{ }^{32} \mathrm{P}\right]$ orthophosphate was accomplished according to Miyamoto et al. (1985). To lower endogenous pools of methionine or free phosphate, cells were washed and incubated for $30 \mathrm{~min}$ in either methionine-free or phosphate-free modified Grace's medium. Nuclear extracts from the labeled cells were prepared as above, with buffer $\mathrm{C}$ containing $0.6 \mathrm{M} \mathrm{NaCl}$. Pulse-chase experiments were carried out as follows. After a 30-min incubation in methionine-free medium, cells were incubated with $100 \mu \mathrm{Ci}$ of $\left[{ }^{35} \mathrm{~S}\right]$ methionine $(1106 \mathrm{Ci} / \mathrm{mM}$, New England Nuclear) per milliliter for $5 \mathrm{~min}$, followed by three washes and incubation in complete Grace's medium for the designated times.

Alkaline phosphatase digestion of the Hox-1.3 protein was carried out by mixing $20 \mu \mathrm{l}$ of the Hox-1.3 protein containing extract $(\sim 40 \mu \mathrm{g}$ total protein) with an equal volume of $E$. coli alkaline phosphatase ( $\sim 4$ units, type $111-\mathrm{N}$, Sigma) in $50 \%$ glycerol, $0.5 \mathrm{mM} \mathrm{MgCl}, 0.5 \mathrm{mM} \mathrm{ZnCl}_{2}$, and $5 \mathrm{mM}$ Tris- $\mathrm{HCl} / \mathrm{pH}$ 8.5). After $1 \mathrm{hr}$ at $37^{\circ} \mathrm{C}, 400 \mu \mathrm{l}$ of RIPA buffer containing $0.5 \mathrm{M}$ $\mathrm{NaCl}, 0.1 \%$ SDS, $0.5 \%$ sodium deoxycholate, $1 \%$ Triton $\mathrm{X}-100$, $0.5 \mathrm{mM}$ PMSF, and $50 \mathrm{mM}$ Tris- $\mathrm{HCl}(\mathrm{pH} 7.5)$ was added to the mixture and Hox-1.3 proteins were immunoprecipitated as described below.

Immunoprecipitations of nuclear extracts containing radiolabeled proteins were performed using the following protocol.

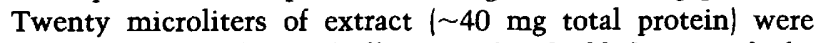
added to $400 \mu \mathrm{l}$ of RIPA buffer, mixed and added to $50 \mathrm{ml}$ of a $1: 1$ (vol/vol) mixture of protein A-Sepharose 4B (Pharmacia) and RIPA buffer. This mixture was incubated on ice with occasional mixing for $30 \mathrm{~min}$. The protein A-Sepharose was removed by a $30-\mathrm{sec}$ centrifugation in an Eppendorf centrifuge and ascites fluid containing the 1D-9 antibody (final dilution $1: 500$ ) was added to the supernatant. After $3 \mathrm{hr}$ of gentle rocking at $4^{\circ} \mathrm{C}, 50 \mu \mathrm{l}$ of fresh $1: 1$ mixture of protein A-Sepharose/RIPA buffer was added and incubated for an additional 45 
$\min$ at $4^{\circ} \mathrm{C}$. The Sepharose beads were washed two times by centrifugation, followed by resuspension in $400 \mu \mathrm{l}$ of RIPA buffer, transferred to a new Eppendorf tube, and washed two additional times as above. After one final wash in $400 \mu$ l of PBS $(\mathrm{pH} 7.5)$, the beads were heated in an equal volume of SDS-gel electrophoresis sample buffer ( $40 \%$ glycerol, $4 \%$ SDS, $3 \%$ DTT, $0.005 \%$ bromphenol blue, and $60 \mathrm{mM}$ Tris- $\mathrm{HCl}$ at $\mathrm{pH} 6.8$ ) at $100^{\circ} \mathrm{C}$ for $10 \mathrm{~min}$. After removal of the beads by centrifugation, the proteins in the supernatant were resolved by electrophoresis through $12.5 \%$ SDS-polyacrylamide gels according to the method of Laemmli (1970). The electrophoresed gels were soaked in autoradiographic enhancer solution (Enlightning, DuPont) for $30 \mathrm{~min}$, dried, and exposed to X-ray film at $-70^{\circ} \mathrm{C}$ with an intensifying screen.

\section{DNase I footprinting}

DNase I footprint analysis was carried out according to the protocol described by Lichtsteiner et al. (1987). Approximately $1 \mathrm{ng}$ of the 310-bp end-labeled XhoI-SacI Hox-1.3 promoter region fragment $\left(2 \times 10^{4} \mathrm{cpm}\right)$ was added to a reaction mixture containing $25 \mathrm{mM}$ HEPES ( $\mathrm{pH} 7.6$ ), and $100 \mathrm{mM} \mathrm{KCl}, 7.5 \%$ (vol/vol) glycerol, $0.1 \mathrm{~mm}$ EDTA, $0.75 \mathrm{~mm}$ DTT, $5 \mathrm{mM} \mathrm{MgCl}_{2}$, and $1 \mu \mathrm{g}$ double-stranded poly[d(I-C)] DNA. Nuclear extracts were mixed in last by gentle pipetting (final volume of reactions was $50 \mu \mathrm{l}$ ). The binding reaction continued for $90 \mathrm{~min}$ on ice. One microliter of DNase I (50-100 $\mu \mathrm{g} / \mathrm{ml}$, Boehringer-Mannheim), prepared according to Lichtsteiner et al. (1987), was then added to the reaction mixture by gentle pipetting. After $90 \mathrm{sec}$ on ice, the digestions were stopped by the addition of $100 \mu \mathrm{l}$ of solution containing $100 \mu \mathrm{g} / \mathrm{ml}$ proteinase $\mathrm{K}, 200 \mathrm{mM} \mathrm{KCl}$, and 100 $\mathrm{mM}$ Tris- $\mathrm{HCl}(\mathrm{pH} 7.5)$. After $45 \mathrm{~min}$ at $45^{\circ} \mathrm{C}$, the nucleic acids were extracted twice with phenol, followed by one chloroform extraction, and precipitated with 2.5 volumes of ethanol. The pellets were resuspended in sample buffer and electrophoresed through a $6 \%$ polyacrylamide $-7 \mathrm{M}$ urea sequencing gel. The gels were dried and autoradiographed at $-70^{\circ} \mathrm{C}$ with an intensifying screen.

\section{Preparation, annealing, and end-labeling of oligonucleotides}

Using cyanoethyl-phosphoramidite chemistry, 26- and 27base-long complementary oligonucleotides loverlapping to create $5^{\prime}$-protruding ends) were synthesized on an Applied Biosystems $380-A$ DNA synthesizer. After deblocking $165^{\circ} \mathrm{C}$ for $\geqslant$ $6 \mathrm{hr}$ ) and lyophylization, the oligonucleotides were resuspended in deionized water, phenol extracted twice, followed by one chloroform extraction and ethanol precipitated. The pellets were resuspended in $100 \mathrm{~mm} \mathrm{NaCl}, 10 \mathrm{mM}$ Tris- $\mathrm{HCl}$ ( $\mathrm{pH} \mathrm{8.0)}$ ), and $1 \mathrm{mM}$ EDTA. The complementary pairs were annealed by mixing $1 \mathrm{mg} / \mathrm{ml}$ of each (final concentration) in $50 \mu \mathrm{l}$ of 100 $\mathrm{mM} \mathrm{NaCl}$, TE (pH 8.0$)$, heating $\left(85^{\circ} \mathrm{C}\right.$ for $10 \mathrm{~min}$ ), followed by slow cooling. End labeling by filling in $5^{\prime}$-protruding ends with the Klenow enzyme to create 30 -bp fragments, each containing three $\left[\alpha^{-32} \mathrm{P}\right] \mathrm{dCTPs}$, was performed according to Maniatis et al. (1982). Upper strand sequences of the annealed oligonucleotides are shown in Table 1.

\section{Southwestern analyses}

The protocol developed by Miskimins et al. (1985) for the detection of DNA-binding proteins in crude nuclear extracts fractionated by SDS-polyacrylamide gel electrophoresis was employed with the following modifications. Hox-1.3 protein-containing extract was fractionated by electrophoresis through a $12.5 \%$ polyacrylamide-SDS gel and transferred onto nitrocellulose according to Towbin et al. (1979). After blocking in binding buffer $[120 \mathrm{mM} \mathrm{NaCl}, 5 \mathrm{~mm} \mathrm{MgCl}, 0.5 \mathrm{mM} \mathrm{DTT}$, and $25 \mathrm{mM}$ HEPES (pH 7.9)] supplemented with $5 \%$ nonfat dry milk at $4^{\circ} \mathrm{C}$ for $1 \mathrm{hr}$, nitrocellulose strips were transferred to the above buffer containing $0.25 \%$ nonfat dry milk, $1 \mu \mathrm{g}$ poly$[\mathrm{d}(\mathrm{I}-\mathrm{C})] / \mathrm{ml}$, and $10^{6} \mathrm{cpm} / \mathrm{ml}$ of radiolabeled probe DNA. Synthetic, catenated DNA probes (mean length of $\sim 120 \mathrm{bp}$ ) that contain either multimers of the $a-b$ footprinted sequence or $a$ nonspecific sequence shown below were prepared and nick translated-using $\left[\alpha^{-32} \mathrm{P}\right] \mathrm{dCTP}$ - according to Vinson et al. 1988.

\section{5'-TACCCCATTAGTGCG-3' a-b monomer $3^{\prime}$-GGTAATCACGCATGG-5'}

\section{5'-TAGCCACGACTTGCG-3' 3'-GTGCTGAACGCATCG-5'}

nonspecific monomer

After gentle shaking at $4^{\circ} \mathrm{C}$ for $6 \mathrm{hr}$, the strips were washed over a 30 -min period with three changes of binding buffer containing $0.25 \%$ dry milk, air-dried, and exposed to X-ray film overnight with an intensifying screen at $-70^{\circ} \mathrm{C}$. Immunoblot analyses of the same strips were carried out using the 1D-9 monoclonal, as described above.

\section{Electrophoretic mobility shift assays}

Protein-DNA complexes were resolved in low ionic strength $9.5 \%$ polyacrylamide gels as described initially by Carthew et al. (1985), with the following modifications. Two microliters of nuclear extracts $(\sim 4 \mu \mathrm{g}$ total protein) were added to binding buffer (final volume, $20 \mu \mathrm{l}$ ) containing 1.0 or $4.0 \mu \mathrm{g}$ of poly[ d(I-C)] (Pharmacia), 100-800 mM KCl (Fig. 8), 12\% glycerol, 12 mM HEPES/NaOH $(\mathrm{pH} 7.9), 4 \mathrm{~mm}$ Tris- $\mathrm{HCl}$ (pH 7.9), $1 \mathrm{~mm}$ EDTA, $1 \mathrm{mM}$ DTT, $300 \mu \mathrm{g} / \mathrm{ml} \mathrm{BSA}, 5 \mathrm{mM} \mathrm{MgCl}_{2}$, and $2 \times 10^{4}$ $\mathrm{cpm}$ of ${ }^{32} \mathrm{P}$-end-labeled oligonucleotide $(0.2-0.8 \mathrm{ng})$. After 90 min on ice, $5 \mu \mathrm{l}$ of $10 \%$ Ficoll, $0.1 \%$ bromphenol blue, $0.1 \%$ xylene cyanol FF, 1 mM EDTA, $3.3 \mathrm{~mm}$ sodium acetate, and 6.7 $\mathrm{mM}$ Tris- $\mathrm{HCl}(\mathrm{pH} 7.9)$ was added. For antibody incubations, $1 \mu \mathrm{l}$ of ascites fluid (diluted 1-10 in binding buffer) was added to the binding reaction $30 \mathrm{~min}$ prior to the addition of the sample buffer. Six microliters of the above mixture were carefully layered onto a pre-electrophoresed $\left(30 \mathrm{~min}, 20 \mathrm{~mA}\right.$, at $\left.4^{\circ} \mathrm{C}\right)$ low ionic strength $9.5 \%$ polyacrylamide gel (acrylamide/bisacrylamide $30: 0.8 ; 1 \mathrm{~mm}$ EDTA; $3.3 \mathrm{~mm}$ sodium acetate; $5 \%$ (vol/ vol) glycerol, and $6.7 \mathrm{~mm}$ Tris- $\mathrm{HCl}(\mathrm{pH} 7.5)$. Electrophoresis was performed for at least $3 \mathrm{hr}\left(20 \mathrm{~mA}\right.$ at $\left.4^{\circ} \mathrm{C}\right)$, with recirculation of the running buffer ( $1 \mathrm{mM}$ EDTA, $3.3 \mathrm{mM}$ sodium acetate, and $6.7 \mathrm{mM}$ Tris- $\mathrm{HCl}$ at $\mathrm{pH}$ 7.5. Gels were dried and exposed to X-ray film overnight at room temperature.

\section{Acknowledgments}

We thank Hilary A. Overton for introducing the baculovirus expression system to W.F.O. We are also grateful to Shawn P. Murphy and Elwood Linney for providing the Hox-1.3 cDNA plasmid. We thank Carl Wu and Paul Shneidman for valuable suggestions concerning the protein/DNA-binding studies, and Victor Friedrich, Susan Parkhurst, and Martin Carden for helpful discussions. We are grateful to Walter B. Kelly for synthesizing the oligonucleotides used in this study. We also thank Judy L. Carrillo for excellent manuscript preparation.

\section{Note added in proof}

After submission of this manuscript, several reports describing divergent homeo domains in known transcription factors have 
been published in this journal and others. Their DNA binding sequences are strikingly similar to those which we have found for the Hox-1.3 protein. We refer the reader to Miranda Robertson's News and Views communication (Nature 336: 522-524, 1988) which cites many of these contributions.

\section{References}

Angel, P., M. Imagawa, R. Chiu, B. Stein, R.J. Imbra, H.J. Rahmsdorf, C. Jonat, P. Herrlich, and M. Karin. 1987. Phorbol ester-inducible genes contain a common cis-element recognized by a TPA-modulated trans-acting factor. Cell 49: 729-739.

Arnheiter, H. and P. Staeheli. 1983. Expression of interferon dependent resistance to influenza virus in mouse embryo cells. Arch. Virol. 76: 127-137.

Arnheiter, H., R.M. Thomas, T. Leist, M. Fountoulakis, and B. Gutte. 1981. Physicochemical and antigenic properties of synthetic fragments of human leukocyte interferon. Nature 294: $278-280$.

Bender, A. and G.F. Sprague, Jr. 1987. MAT $\alpha$-1 protein, a yeast transcription activator, binds synergistically with a second protein to a set of cell-type specific genes. Cell 50: 681-691.

Bohmann, D., T.J. Bos, A. Admon, T. Nishimura, P.K. Vogt, and R. Tjian. 1987. Human proto-oncogene c-jun encodes a DNA-binding protein with structural and functional properties of transcription factor AP-1. Science 238: 1386-1392.

Bürglin, T.R., C.E. Wright, and E.M. De Robertis. 1987. Translational control in homeo box mRNAs? Nature 330: 701702.

Carthew, R.W., L.A. Chodosh, and P.A. Sharp. 1985. An RNA polymerase II transcription factor binds to an upstream element in the adenovirus major late promoter. Cell 43: 439448.

Cho, K., J. Goetz, C. Wright, A. Fritz, J. Hardwicke, and E.M. De Robertis. 1988. Differential utilization of the same reading frame in a Xenopus homeo box gene encodes two related proteins sharing the same DNA-binding specificity. $E M B O$ I. 7: 2139-2149.

Desplan, C., J. Theis, and P.H. O'Farrell. 1985. The Drosophila developmental gene, engrailed, encodes sequence-specific DNA binding activity. Nature 318: 630-635.

Dignam, J.D., R.M. Lebowitz, and R.G. Roeder. 1983. Accurate transcription initiation by RNA polymerase II in a soluble extract from isolated mammalian nuclei. Nucleic Acids Res. 11: 1475-1489.

Dorn, A., J. Bollekens, A. Staub, C. Benoist, and D. Mathis. 1987. A multiplicity of CCAAT box-binding proteins. Cell 50: $863-872$.

Driever, W. and C. Nüsslein-Volhard. 1988. The bicoid protein determines position in the Drosophila embryo in a concentration-dependent manner. Cell 54: 93-105.

Eisenberg, S., C. Civalier, and B.K. Tye. 1988. Specific interaction between a Saccharomyces cerevisiae protein and a DNA element associated with certain autonomously replicating sequences. Proc. Natl. Acad. Sci. 85: 743-746.

Elias, P. and J.R. Lehman. 1988. Interaction of origin binding protein with an origin of replication of herpes simplex virus 1. Proc. Natl. Acad. Sci. 82: 5423-5427.

Fainsod, A., L.D. Bogarad, T. Ruusala, M. Lubin, D.M. Crothers, and F.H. Ruddle. 1986. The homeodomain of a murine protein binds $5^{\prime}$ to its own homeo box. Proc. Natl. Acad. Sci. 83: 9532-9536.

Fibi, M., B. Zink, M. Kessel, A.M. Colberg-Poley, S. Labeit, H.
Lehrach, and P. Gruss. 1988. Coding sequence and expression of the homeo box gene Hox-1.3. Development 102: 349-359.

Gay, N.J., S.J. Poole, and T.B. Kornberg. 1988. The Drosophila engrailed protein is phosphorylated by a serine-specific protein kinase. Nucleic Acids Res. 16: 6637-6647.

Gehring, W.J. 1987. Homeo boxes in the study of development. Science 236: $1245-1252$.

Harding, K., C. Weden, W. McGinnis, and M. Levine. 1985. Spatially regulated expression of homeotic genes in Drosophila. Science 229: 1236-1242.

Harshman, K.D., W.S. Moye-Rowley, and C.S. Parker. 1988. Transcriptional activation by the SV40 AP- 1 recognition element in yeast is mediated by a factor similar to AP-1 that is distinct from GCN4. Cell 53: 321-330.

Hart, C.P., A. Fainsod, and F.J. Ruddle. 1987. Sequence analysis of the murine Hox 2.2, 2.3 and 2.4 homeo boxes: Evolutionary and structural comparisons. Genomics 1: 182-195.

Hiromi, Y. and W.J. Gehring. 1987. Regulation and function of the Drosophila segmentation gene fushi tarazu. Cell 50: $963-974$.

Hoey, T. and M. Levine. 1988. Divergent homeo box proteins recognize similar DNA sequences in Drosophila. Nature 332: $858-861$.

Holland, P.W.H. and B.L.M. Hogan. 1986. Phylogenetic distribution of Antennapedia-like homeo boxes. Nature 321: 251-253.

. 1988. Expression of homeo box genes during mouse development: A review. Genes Dev. 2: 773-782.

Jones, K.A., J.T. Kadonaga, P.J. Rosenfeld, T.J. Kelly, and R. Tijan. 1987. A cellular DNA-binding protein that activates eukaryotic transcription and DNA replication. Cell 48: 7989.

Kristie, T.M. and B. Roizman. 1987. Host cell proteins binds to the cis-acting site required for virion-mediated induction of the herpes simplex virus $1 \alpha$ genes. Proc. Natl. Acad. Sci. 84: $71-75$.

Krumlauf, R., P.W.H. Holland, J.H. Mc Vey, and B.L.M. Hogan. 1987. Developmental and spatial patterns of expression of the mouse homeo box gene Hox 2.1. Development 99: 603617.

Laemmli, U.K. 1970. Cleavage of structural proteins during the assembly of the head of bacteriophage T4. Nature 227: 680685.

Laughon, A. and M.P. Scott. 1984. Sequence of a Drosophila segmentation gene: Protein structure homology with DNAbinding proteins. Nature 310: 25-31.

Lee, W., P. Mitchell, and R. Tjian. 1987. Purified transcription factor AP-1 interacts with TPA-inducible enhancer elements. Cell 49: 741-752.

Lichtsteiner, S., J. Wuarin, and U. Schibler. 1987. The interplay of DNA-binding proteins on the promoter of the mouse albumin gene. Cell 51: 963-973.

Mackem, S. and B. Roizman. 1982. Structural features of the herpes simplex vinus alpha gene 4,0 , and 27 promoter-regulatory sequences which confer alpha regulation on chimeric thymidine kinase genes. I. Virol. 44: 939-949.

Maniatis, T., E.F. Fritsch, and J. Sambrook. 1982. Molecular cloning: A laboratory manual. Cold Spring Harbor Laboratory, Cold Spring Harbor, New York.

Matsuura, Y., R.D. Possee, and D.H.L. Bishop. 1986. Expression of the S-coded genes of lymphocytic choriomeningitis arenavirus using a baculovirus vector. I. Gen. Virol. 67: 1515-1529.

McGinnis, W. 1985. Homeobox sequences of the Antennapedia 
class are conserved only in higher animal genomes. Cold Spring Harbor Symp. Quant. Biol. 50: 263-270.

McGinnis, W., M. Levine, E. Hafen, A. Kuroiwa, and W.J. Gehring. 1984. A conserved DNA sequence in homeotic genes of the Drosophila Antennapedia and bithorax complexes. Nature 308: 428-433.

Merrifield, R.B. and G. Barany. 1980. The peptides, analysis, synthesis, biology (ed. E. Gross and J. Meinenhofer), vol. 2, chapter 1. Academic Press, New York.

Miskimins, W.K., M.P. Roberts, A. McClelland, and F.H. Ruddle. 1985. Use of a protein-blotting procedure and a specific DNA probe to identify nuclear proteins that recognize the promoter region of the transferring receptor gene. Proc. Natl. Acad. Sci. 82: 6741-6744.

Miyamoto, C., G.E. Smith, J. Farrell-Towt, R. Chizzonite, M.D. Summers, and G. Ju. 1985. Production of human c-myc protein in insect cells infected with a baculovirus expression vector. Mol. Cell Biol. 5: 2860-2865.

Monteil, J.F., C.J. Norbury, M.F. Tuite, M.J. Dobson, J.S. Mills, A.J. Kingsman, and S.M. Kingsman. 1984. Characterization of human chromosomal DNA sequences which replicate autonomously in Saccharomyces cerevisiae. Nucleic Acids Res. 12: 1049-1068.

Moskaluk, C. and D. Bastia. 1988. DNA bending is induced in an enhancer by the DNA-binding domain of the bovine papillomavirus E2 protein. Proc. Natl. Acad. Sci. 85: 18261830.

Murphy, S.P., J. Garbern, W.F. Odenwald, R.A. Lazzarini, and E. Linney. 1988. Differential expression of the homeo box gene Hox-1.3 in F9 embryonal carcinoma cells. Proc. Natl. Acad. Sci. 85: 5587-5591.

Nüsslein-Volhard, C., and E. Wieschaus. 1980. Mutations affecting segment number and polarity in Drosophila. Nature 287: 795-801.

Odenwald, W.F., C.F. Taylor, F.J. Palmer-Hill, V. Friedrich, M. Tani, and R.A. Lazzarini. 1987. Expression of a homeo domain protein in noncontact-inhibited cultured cells and postmitotic neurons. Genes Dev. 1: 482-496.

Ouweneel, W. 1976. Developmental genetics of homeosis. Adv. Genet. 16: 179-248.

Palzkill, T.G. and C.S. Newlon. 1988. A yeast replication origin consists of multiple copies of a small conserved sequence. Cell 53: 441-450.

Parslow, T.G., D.L. Blair, W.J. Murphy, and D.K. Granner. 1984. Structure of the $5^{\prime}$ ends of immunoglobin genes: A novel conserved sequence. Proc. Natl. Acad. Sci. 81: 2650-2654.

Preston, C.M., M.C. Frame, and M.E.M. Campbell. 1988. A complex formed between cell components and an HSV structural polypeptide binds to a viral immediate early gene regulatory DNA sequence. Cell 52: 425-434.

Pruijn, G.J.M., W. van Driel, R.T. van Miltenburg, and P.C. van der Vliet. 1987. Promoter and enhancer elements containing a conserved sequence motif are recognized by nuclear factor III, a protein stimulating adenovirus DNA replication. $E M B O$ I. 6: 3771-3778.

Rabbitts, T.H., A. Forster, R. Baer, and P.H. Hamlyn. 1983. Transcription enhancer identified near the human $\mathrm{C}-\mu \mathrm{im}$ munoglobin heavy chain gene is unavailable to the translocated c-myc gene in a Burkitt lymphoma. Nature 306: 806809.

Rawlins, D.R., G. Milman, S.D. Hayward, and G.S. Hayward. 1985. Sequence-specific DNA-binding of the Epstein-Barr virus nuclear antigen (EBNA-1) to clustered sites in the plasmid maintenance region. Cell 42: 859-868.

Reisman, D., J. Yates, and B. Sugden. 1985. A putative origin of replication of plasmids derived from the Epstein-Barr virus is composed of two cis-acting components. Mol. Cell. Biol. 5: $1822-1832$.

Richardson, C.D., A. Berkovich, S. Rozenblatt, and W.J. Bellini. 1985. Use of antibodies directed against synthetic peptides for identifying cDNA clones, establishing reading frames, and deducing the gene order of measles virus. J. Virol. 54: 186-193.

Rosales, R., M. Vigneron, M. Macchi, I. Davidson, J.H. Xiao, and P. Chambon. 1987. In vitro binding of cell-specific and ubiquitous nuclear proteins to the octamer motif of the SV40 enhancer and related motifs present in other promoters. EMBO 7 . 6: 3015-3025.

Rosenfeld, P.J., E.A. O'Neill, R.J. Wides, and T.J. Kelly. 1987. Sequence-specific interactions between cellular DNAbinding proteins and the adenovirus origin of DNA replication. Mol. Cell. Biol. 7: 875-886.

Santoro, C., N. Mermod, P.C. Andrews, and R. Tjian. 1988. A family of human CCAAT-box binding proteins active in transcription and DNA replication: Cloning and expression of multiple cDNAs. Nature 334: 218-224.

Scott, M.P. and A.J. Weiner. 1984. Structural relationships among genes that control development: Sequence homology between the Antennapedia, Ultrabithorax and fushi tarazu loci of Drosophila. Proc. Nat1. Acad. Sci. 81: 4115-4118.

Shaw, G. and R. Kamen. 1986. A conserved AU sequence from the 3' untranslated region of GM-CSF mRNA mediates selective mRNA degradation. Cell 46: 659-667.

Shepherd, J.C.W., W. McGinnis, A.E. Carrasco, E.M. De Robertis, and W.J. Gehring. 1984. Fly and frog homeo domains show homologies with yeast mating type regulatory proteins. Nature 310: 70-71.

Smith, G.E., M.D. Summers, and M.J. Fraser. 1983. Production of human beta interferon in insect cells infected with a baculovirus expression vector. Mol. Cell. Biol. 3: 2156-2165.

Sturm, R., T. Baumruker, B.R. Franza, Jr., and W. Herr. 1987. A $100-\mathrm{kD}$ HeLa cell octamer binding protein (OBP100) interacts differently with two separate octamer-related sequences within the SV40 enhancer. Genes Dev. 1: 11471160.

Summers, M.D. and G.E. Smith. 1987. A manual of methods for baculovirus vectors and insect cell culture procedures. Tex. Agric. Exp. Stn. Bull., No. 1555.

Towbin, H., T. Staehelin, and J. Gordon. 1979. Electrophoretic transfer of proteins from polyacrylamide gels to nitrocellulose sheets: Procedure and some applications. Proc. Natl. Acad. Sci. 76: 4350-4354.

Treisman, R. 1985. Transient accumulation of c-fos RNA following serum stimulation requires a conserved 5 ' element and c-fos 3' sequences. Cell 42: 567-574.

Triezenberg, S.J., K.L. LaMarco, and S.L. McKnight. 1988. Evidence of DNA: Protein interactions that mediate HSV-1 immediate early gene activation by VP16. Genes Dev. 2: 730742.

Verrijzer, P., W. de Graaf, J. Deschamps, and F. Meijlink. 1988. Nucleotide sequence of the Hox 2.3 gene region. Nucleic Acids Res. 16: 2729.

Vinson, C.R., K.L. LaMarco, P.F. Johnson, W.H. Landschulz, and S.L. McKnight. 1988. In situ detection of sequence-specific DNA-binding activity specified by a recombinant bacteriophage. Genes Dev. 2: 801-806.

Weller, S.K., A. Spadaro, J.E. Schaffer, A.W. Murray, A.M. Maxam, and P.A. Schaffer. 1985. Cloning, sequencing, and functional analysis of ori $_{L}$, a herpes simplex virus type I origin of DNA synthesis. Mol. Cell. Biol. 5: 930-942. 


\section{Odenwald et al.}

Wides, R.J., M.D. Challberg, D.R. Rawlins, and T.J. Kelly. 1987. Adenovirus origin of DNA replication: Sequence requirements for replication in vitro. Mol. Cell. Biol. 7: 864-874.

Zenke, M., T. Grundstrom, H. Matthes, M. Wintzereith, C. Schatz, A. Wildeman, and P. Chambon. 1986. Multiple sequence motifs are involved in SV40 enhancer function. EMBO I. 5: 378-397. 


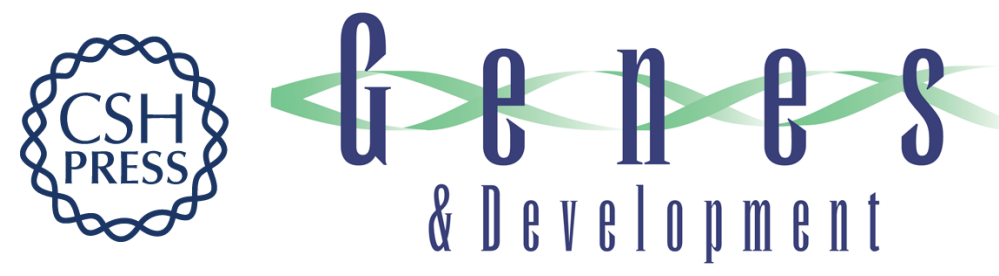

\section{The Hox-1.3 homeo box protein is a sequence-specific DNA-binding phosphoprotein.}

W F Odenwald, J Garbern, H Arnheiter, et al.

Genes Dev. 1989, 3:

Access the most recent version at doi:10.1101/gad.3.2.158

References This article cites 68 articles, 28 of which can be accessed free at:

http://genesdev.cshlp.org/content/3/2/158.full.html\#ref-list-1

License

Email Alerting Receive free email alerts when new articles cite this article - sign up in the box at the top Service right corner of the article or click here.

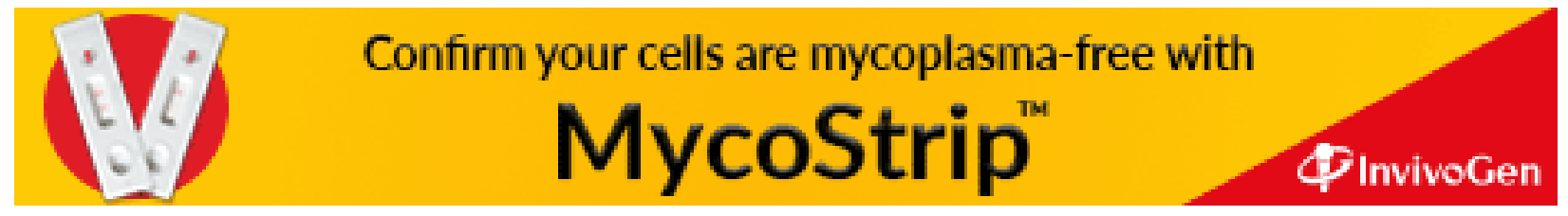

